Віталій Рахманов,

доктор педагогічних наук, доцент Національний університет оборони України імені Івана Черняховського

ORCID ID 0000-0002-7180-4087

DOI: $10.33099 / 2617-1775 / 2020-01 / 243-263$

\title{
ТЕОРЕТИЧНІ ЗАСАДИ ПІДГОТОВКИ ОФІЦЕРІВ В УМОВАХ ОСВІТНЬО-ІНФОРМАЩЙННОГО СЕРЕДОВИЩА ВИЩОГО ВІЙСЬКОВОГО НАВЧАЛЬНОГО ЗАКЛАДУ
}

У статті розглядаються особливості інтегрування офіиера в освітньо-інформаційне середовище, щчо визначається представленням елементів освітньо-інформаційного середовища як таких, щзо опрацьовують (специфічним чином) інформацію та описують прочеси в ньому. Також було встановлено, щуо дочільно розглядати освітньо-інформаційне середовище не як механічну систему, у яку інтегрується офіцер, а як систему 3 функиіональним інтегруванням «офіцер- ОІС». Крім того, розглянуто технологію навчання, щзо полягає у сукупності методів та засобів для реалізації відповідного змісту підготовки в умовах освітньо-інформаційного середовища. У роботі проаналізовано, щуо при наявності розвиненої інформаційної бази нові поняття тепер можуть засвоюватися, в основному, за аналогією з тим, щчо уже відомо, $і$ головною проблемою стає включення нового знання в існуючу структуру: як тільки встановлено правильне співвідношення, весь обсяг минулого досвіду автоматично залучається до тлумачення $і$ розуміння нових подій, яке розвивається иляхом взаємодіі зовнішнього досвіду з внутрішніми механізмами, щзо оперують інформацією, яка надходить, і реорганізують їі.

Ключові слова: освітньо-інформачійне середовище; підготовка офіиерів; вищій військовий навчальний заклад.

Постановка проблеми. В умовах розбудови демократичної держави докорінно змінюється ситуація в системі військової освіти, гостро постає необхідність ii динамічного розвитку та вдосконалення. Проведений аналіз результатів досліджень свідчить про те, що концепція сучасної військової освіти повинна передбачати сучасні дидактичні, інформаційні, телекомунікаційні, інформаційні технології, а також наукового розв'язання актуальних проблем підготовки військового фахівця, які пов'язані 3 подоланням: упровадженням технологій навчання, автоматизацією й інформатизацією процесу підготовки офіцерів, моделюванням навчального процесу у ВВНЗ $[1,2,5,9,15,27,30,34,38,40,41,42,43,46]$. У зв'язку з цим, має змінитися і сам підхід до підготовки офіцерів ВВНЗ, оволодіння ним професійних компетентностей. Головним $\epsilon$ не просте накопичення знань, досвіду за певними програмами та алгоритмами, а сформованість фахових компетентностей. Тому на сучасному етапі існує актуальна проблема пошуку ефективних шляхів підготовки офіцерів у ВВНЗ.

Одним з головних пріоритетів в освітньому процесі ВВНЗ є прагнення побудувати навчання таким чином, щоб підготовка була орієнтована на інтереси офіцерів; спрямована на розвиток інформаційного середовища, в якому кожен офіцер міг би накопичувати інформацію та створювати знання, 
мати до них вільний доступ; користуватися і обмінюватися інформацією, щоб надати можливість кожному фахівцю повною мірою реалізувати свій потенціал, сприяючи суспільному і особистому розвитку. Наукові дослідження, які присвячені проблемам особистісно-орієнтованої освіти, моделювання та технологізації навчання, програмованого навчання, психолого-педагогічних закономірностей використання інформаційних систем, програмованого навчання та розробки навчальних систем, сприйняття електронної інформації, формування освітньо-інформаційного середовища (OIC) навчального закладу $[8,12,21,23]$, надають можливість побудувати та організувати освітній процес за допомогою інформаційних систем. Це дозволить:

- підвищити якість підготовки за рахунок використання військовими викладачами професійної інформації та розширенням діапазону інформаційних потреб різних напрямів підготовки офіцерів, забезпечення прозорості та об'єктивності систем моніторингу якості освіти;

- усунення територіальних бар'єрів в процесі навчання офіцерів за рахунок освітньо-інформаційного середовища, забезпечення мотивованої самостійної роботи офіцерів при оволодінні нових знань;

- суттєве прискорення руху навчальної інформації, автоматизацію процесів організації та управління освітніми процесами.

Аналіз останніх досліджень і публікацій. Аналіз вітчизняної та зарубіжної науково-педагогічної літератури $[1,2,5,9,15,27,30,34,38,40,41$, $42,43,46]$ свідчить, що впровадження освітньо-інформаційного середовища у закладах вищої освіти спрямоване на:

- створення єдиного освітньо-інформаційного оточення;

- управління освітнім процесом та забезпечення наступності практичного досвіду всередині закладу вищої освіти;

- $\quad$ формування сучасних підходів до освітнього процесу;

- підвищення інформаційної культури закладу вищої освіти.

У цьому є підтвердження в роботах Г. Лаурейса та Х. Ріддер-Сімоенса, які вивчали проблему періодизації академічної мобільності; у дослідженнях С. Маргінсона, Дж. Найта, У. Тайхлера, які визначали тенденції та перспективи розвитку освітнього процесу в різних регіонах світу; в працях С. ВінсентЛанкріна та Ф. Мюхе, які, аналізуючи мотивацію суб’єктів організації людської мобільності, досліджували стратегії переміщення іноземних слухачів до закладів вищої освіти інших країн $[30,33]$.

Дослідження українських вчених В.Ю. Бикова, О.В. Діденка, Г.О. Козлакової, Л.І. Морської, О.М. Спіріна, Т.В. Тихонової, М.І. Шермана, які присвячені проблемам навчання за допомогою інформаційних систем, дозволяють визначити напрями застосування персональних електроннообчислювальних машин в освіті, розробити дидактичні та технологічні принципи формування та функціонування відкритих систем навчання. У той же час недостатньо досліджена проблема інтеграції закладів ВВНЗ з освітньоінформаційним середовищем, під яким ми будемо розуміти відкриту освітню систему, що акумулює інтелектуальні, культурні, програмно-методичні, 
організаційні та технічні ресурси [36]. Саме тому побудова освітньоінформаційного середовища на базі сучасних інформаційних технологій привносить в освітній процес закладів вищої військової освіти такі можливості, як: поєднання високої економічної ефективності та гнучкості освітнього процесу з суттєвим розширенням можливостей традиційних форм навчання, а також перспективу створення нових ефективних форм навчання [35]. Такий висновок можливий за умов, що єдине інформаційне середовище дозволяє в процесі освітньої діяльності оптимально і якісно здійснювати:

- планування освітнього процесу за різними програмами, рівнями та формами навчання;

- організацію в електронній формі навчальних занять та представлення навчального матеріалу у довідковій формі;

- перехід від домінування репродуктивної освітньої діяльності до творчої;

- надання доступу офіцерам до інформації, пов'язаної з плануванням, організацією та моніторингом освітнього процесу;

- забезпечення комунікативної взаємодії між військовим викладачами, офіцерами-слухачами та управлінським апаратом ВВН3;

- ефективне використання у змістовому процесі освіти навчальнометодичних комплексів і матеріалів, які постійно оновлюються.

Мета статті полягає у дослідженні особливості інтегрування офіцера в освітньо-інформаційне середовище, що визначається представлення елементів OIC, як таких, що опрацьовують інформацію та описують процеси в ньому.

Виклад основного матеріалу. Так, інформаційні центри, науковометодичні і навчальні лабораторії та військові кафедри військового закладу наповнюючи освітньо-інформаційне середовище навчально-методичними електронними комплексами, сприяють створенню і впровадженню у освітній процес ВBН3:

- електронних підручників, що включають науково-обгрунтований теоретичний матеріал, глосарій, теми лабораторних робіт та проблемні завдання для практичних занять, зразки контрольних питань та тестових завдань;

- плани лекційних і практичних занять;

- навчальні завдання для самостійної роботи та вимоги до них;

- завдання до підсумкової атестації;

- опис інформаційних засобів та технологій, необхідних для виконання навчальних завдань;

- методичні вказівки до використання даного комплексу;

- основні дискусійно-проблемні та професійно-орієнтовані завдання;

- електронні зв'язки (посилання) у мережі «Інтернет» на довідкові інформаційні ресурси з дисципліни;

- додаткові навчальні матеріали (підручники, навчальні посібники, збірники наукових праць, журнали тощо).

Таким чином, можна відмітити, що одним 3 компонентів єдиного інформаційного середовища є вільні ресурси мережі Інтернет, які активно 
використовуються в освітньому процесі ВВНЗ. Крім того, освітньоінформаційне середовище включає апаратні, програмні та інформаційні комплекси, способи використання яких регламентуються науково-методичним забезпеченням освітнього процесу. Так, на заняттях в інтерактивному кабінеті, який підключений до єдиної мережі освітньо-інформаційного середовища ВВН3, максимально можуть використовуватися наступний потенціал інформаційних технологій, а саме: комп'ютерна аудиторія включає такі процеси, як підготовку навчального матеріалу, проведення занять, інтерактивне тестування, опитування й дискусії, моніторинг знань офіцерів [10]. При цьому, під час занять можуть бути використані як електронні підручники й цифрові освітні ресурси, так i авторські розробки, які підготовлені науковопедагогічними працівниками [13], що в подальшому, ефективно використовується для самостійної підготовки офіцерів, обміну досвідом і спільної підготовки навчального матеріалу військовими викладачами [11].

Одним із найважливіших компонентів єдиного освітньо-інформаційного середовища ВВН3 $є$ електронна бібліотека, що, будучи повноправним учасником відкритого синергетичного освітнього процесу, забезпечує доступ до каталогів бібліотеки закладу вищої освіти (наприклад, електронна бібліотека Національного університету оборони України імені Івана Черняховського (НУОУ) - (nuou.org.ua), інших бібліотек (наприклад, Dropbox) та бібліотек, 3 якими укладені договори про співробітництво, розширюючи, таким чином, освітньо-інформаційне середовище для отримання відповідних послуг. Визначаючи роль та місце електронної бібліотеки НУОУ в ОІС закладу вищої військової освіти, необхідно відмітити, що однією із найважливіших умов успішного функціонування освітнього процесу є оперативний та ефективний обмін інформацією, яку надають електронні ресурси. Виконуючи основну бібліотечну функцію - зберігання не лише своєї, але й світової навчальної інформації, - електронна бібліотека освітньо-інформаційного середовища ВВНЗ займає особливе місце, виконуючи роль посередника між інформаційними ресурсами та споживачами інформації, вибираючи при цьому, систематизуючи, зберігаючи та пропонуючи найкращі наукові доробки 3 величезного інформаційного масиву. Крім того, освітньо-інформаційне середовище ВВН3, взаємодіючі 3 іншими підрозділами закладів військової освіти, як суб'єктами навчання, дозволяє здійснювати включення закладів вищої військової освіти у європейську співдружність військових університетів та НАТО як гідних і рівноправних членів в різних формах і напрямах, а саме: науково-технічну співпрацю з провідними військовими університетами світу, реалізацію міжнародних освітніх програм і проектів НАТО, здійснення спільної науково-дослідної та видавничої діяльності за стандартами НАТО, організацію міжнародних науково-практичних семінарів і конференцій, обмін військовими викладацькими кадрами і розвиток офіцерської мобільності [47].

У переважній більшості розроблених науково-практичних підходів до освітнього процесу прослідковується використання дидактичних засобів співпраці викладача, офіцера та електронних обчислювальних машин, при цьому, кожна складова (компонент) освітньо-інформаційного середовища має 
свої засоби представлення навчальної інформації й органи керування. Використання такого підходу не завжди формує результат, який би дозволив інтегрувати функціонально офіцера в освітньо-інформаційне середовище, тому що елементи OIC, у переважній більшості, виявляються роздрібненими на інформаційному рівні, а на робочому місці військового викладача формується надмірно велике число органів (елементів) керування ОIC (що відповідає кількості керованих і керуючих об'єктів), які призначені для освітньої діяльності офіцерів.

Здійснюючи аналіз підготовки офіцера в умовах освітньо-інформаційного середовища, за допомогою методу імітаційного моделювання, було встановлено, що доцільно розглядати ОIC не як механічну систему, за допомогою якої офіцер інтегрується в технічні засоби, а як соціоінформаційну систему. В результаті взаємодії офіцера з освітньо-інформаційним середовищем виявлено, що частина інформації може бути не задіяною в періоди навчання, або використовуватися вкрай замало в період функціонування. Отже, при вирішенні завдань функціональної інтеграції офіцера в освітньо-інформаційне середовище, доцільно застосовувати такі методики, які б враховували у повному обсязі структуру і характер нових знань та комп'ютерних засобів в цілому.

Як відомо, одним із напрямів підготовки офіцера є отримання інформації про стан об'єкта дослідження та опрацювання поточної інформації. Результатом фактичного опрацювання $є$ прийняття рішення на визначення відповідних впливів. Як показують проведені дослідження [6], функціональна інтеграція офіцера в освітньо-інформаційне середовище можлива завдяки представлення елементів ОIC, як таких, що опрацьовують (специфічним чином) інформацію та описують процеси в ньому.

Розглядаючи особистість офіцера, як соціально-особистісну систему, яка формує системоутворююче функціональне ядро освітньо-інформаційного середовища щодо одержання, сприймання, опрацювання інформації $\mathrm{i}$, як результат, формування компетентностей на основі керуючих впливів системи, спрямованих на зміну стану елементів освітньо-інформаційного середовища, опишемо більш докладно процеси, що відбуваються в освітньо-інформаційному середовищі як центрального елемента освітнього процесу.

Відповідно до психофізіології пізнавальних процесів людини, пам'ять одна 3 основних властивостей нервової системи особистості, що виражена в спроможності тривалого збереження отриманої інформації про події в оточуючих людину середовищах і реакціях організму на вплив цих середовищ. На основі аналізу і синтезу отриманої інформації, що може багаторазово вводитися в сферу свідомості внутрішніх уявлень офіцера, що, як відомо, формує його індивідуальну модель навчання [20]. Крім того, знання законів процесу накопичення інформації, що відбувається в результаті спільної роботи органів почуттів, дозволяє зрозуміти сутність інтегрування офіцера в освітньоінформаційне середовище на інформаційно-функціональному рівні [28].

Відомо, що на основі мислення, запам'ятовування, сприйняття i накопичення інформації, в головному мозку, відбуваються біохімічні i 
біофізичні процеси [4], які формують, відповідно, динамічні та інтегровані механізми процесу пам'яті. Людина, навчаючись, запам'ятовує інформацію через утворення зв'язків між новим і раніш закріпленим змістом в результаті активної взаємодії із освітнім середовищем. Саме, багатократний вплив (повторення) різних збудників і $€$ основним засобом набуття інформації. Розглядаючи цей постулат як принцип навчання, має сенс віддати йому перевагу тільки в тому випадку, якщо нове поняття ми змушені будувати на місці, яке не зв'язано з інформацією, що зберігається в пам'яті. Проте, в міру накопичення інформації та збільшення обсягу пам'яті, значення цього постулату для розвитку інформаційної бази пам'яті різко знижується. Точніше, необхідність використання принципу багатократного впливу (повторення) виникає епізодично, лише коли необхідно запам'ятати нове поняття з цілком новим обсягом інформації або змістом. У той же час, значення інформації зростає для інтерпретації даних, їхньої оцінки, тобто відбувається структурнологічне перетворення.

В той же час, безупинна еволюція знань, що зберігаються в запам'ятовуючій системі, робить істотний вплив на те, яким чином набувається нова інформація. Так, існує істотна різниця між запам'ятовуванням повідомлення в пам'яті дитини і тим, як записується інформація в дорослі роки. У дитини кожне нове поняття будується практично на порожньому місці, саме тому початковий етап побудови інформаційної бази дитини неминуче пов'язаний 3 величезними обсягами інформації, запам'ятовування якої відбувається автоматичним шляхом за рахунок багатократного повторення. Розуміння ж починає вироблятися лише в міру накопичення ознак предметів, явищ, процесів, узнавання понять і розвитку уявлень про об'ємні відношення сукупностей і класів, а, тому, більшість понять у пам'яті дитини визначено лише частково і слабко пов'язане з іншою збереженою інформацією.

При виконанні бойових завдань офіцерами, коли вже накопичена велика кількість інформації, яка організована в інформаційну базу 3 розвинутою системою перехресних зв'язків, навчання набуває іншого характеру, що визначається не стільки чистим обсягом інформаційної бази, скільки структурою зв'язків самої інформації, що зберігається, i, отже, мало залежить від зовнішніх чинників. Більш того, процес пізнання, якщо ми хочемо придбати дійсні знання, а не автоматичне нескладне накопичення інформації, враховує такі властивості пам'яті, як:

- швидкість запам'ятовування, що визначається кількістю повторень (або часом), які потрібні офіцеру для запам'ятовування нового матеріалу;

- точність запам'ятовування, яку визначають відповідністю відтвореного тому, що запам'ятовували, та кількістю допущених помилок;

- міцність запам'ятовування, що виявляється в тривалості збереження завченого матеріалу (або в повільності його забування);

- готовність до відтворення, яка виявляється в тому, як швидко та легко в потрібний момент людина може пригадати необхідні їй відомості. 
Здавалося б, основна структура пам'яті, як і процедури перетворення інформації, повинна бути в усіх офіцерів однакова. Проте, незважаючи на подібність цих основних механізмів, їх дія не обов'язково призводить до виникнення тих самих структур пам'яті. Навіть дуже тонкі розходження в навколишньому оточенні можуть лишити в пам'яті неоднакові сліди у різних офіцерів, незважаючи на можливу спільність стоячих за ними механізмів інтерпретації і запам'ятовування нового матеріалу.

Припустивши, що гнучкість запам'ятовуючої системи, в обертанні з новою інформацією, постійно зменшується в міру становлення іiі структури, тобто майже усе, із чим зіштовхується офіцер, може бути тим або іншим чином співвіднесено $з$ уже знайомим йому по минулому досвіду і навіть якщо інформація, яка сприймана знаходиться в очевидному протиріччі 3 цим досвідом, його понятійна структура, що виробила настільки складну систему взаємозалежних співвідношень, противиться перегляду. У результаті офіцер схильний скоріше відкинути або переглянути, переосмислити суперечну його досвіду інформацію, чим перебудовувати або видозмінювати систему своїх переконань. Таким чином, побудова внутрішніх уявлень про зовнішні події $\epsilon$ необхідною передумовою людської спроможності мислення, а саме, як тільки на наше уявлення починають діяти внутрішні структури знань, уявні процеси перестають бути в залежності від навколишнього середовища. Нам стає не обов’язковим виконувати ту чи іншу дію для судження про іiї наслідки, тому що всю послідовність подій можна передбачити заздалегідь шляхом мисленевого моделювання (складаючи, тим самим, сутність мислення). Тобто, офіцер може починати мислене моделювання 3 бажаного результату i рухатися в інверсійному напрямку через внутрішні структури, виявляючи потрібні, доцільні, можливі дії й умови, яких варто дотримуватися для досягнення мети на кожному етапі підготовки. Крім того, мислення припускає необхідність моделювати в думці весь сюжет складної дії, робити припущення про нові можливості i маневрувати ними за допомогою символів мови, тобто використовуючи другу сигнальну систему. Проте, основні навички, необхідні для організації i використання сенсомоторних схем (схем виконання організаційної послідовності дій, що складають визначену форму поведінки на основі співвідношення між сприйманою інформацією і необхідними моторними м'язовими діями), зберігають своє першорядне значення на всіх рівнях мислення [16].

Виняткове місце при підготовці офіцера в умовах освітньо-інформаційного середовища приділяється увазі, яка є характеристикою психічної діяльності, що виражається в зосередженості й у спрямованості свідомості на визначений об'єкт, де під спрямованістю свідомості будемо розуміти виборчий характер психічної діяльності, тобто здійснення в ній вибору даного об'єкта $з$ окремого поля можливих об'єктів [25]. Як відомо, розрізняють три види уваги: мимовільну, довільну і післядовільну. Мимовільна (пасивна) увага має місце, коли вибір об'єкта діяльності визначається без заздалегідь поставленої мети, тобто ненавмисно. Якщо ж вибір проводиться свідомо, навмисно, то увага $\epsilon$ довільною (активною), актом волі, властивим тільки людині, яка виникла в 
процесі роботи. В той же час діяльність (навчальна, професійна) може так захопити офіцера, що ії виконання не вимагатиме від неї спеціальних вольових зусиль. Наявність мети в сполученні 3 відсутністю вольових зусиль характеризує післядовільну увагу, яка визначається тривалою високою зосередженістю, пов'язаною з найбільш інтенсивною й плідною розумовою діяльністю, високою продуктивністю усіх видів служби. Саме тому, для того, щоб механізм активного синтезу був здатним побудувати оптимальну внутрішню модель навколишньої дійсності необхідно, щоб вся інформація, яка одержана про об'єкт у вигляді сигналів, зведень, повідомлень, склалася в зрозумілий для офіцера образ. I в залежності від того, наскільки інтенсивно організовується ефективне інтегрування офіцера в систему освітньоінформаційного середовища, головний акцент розумової діяльності переноситься на процес пошуку інформації в пам'яті офіцера.

Розглянемо найбільш важливі, 3 погляду, теорії і практики наукового пізнання і навчання варіанти пошуку й вилучення інформації з пам'яті при підготовці офіцера в умовах освітньо-інформаційного середовища. Для знаходження відповіді на питання (зручніше називати запит) недостатньо мати в пам'яті лише відповідну інформацію. Необхідно відшукати всю інформацію, що відноситься до даного запиту, оцінити суперечність, зіставити результати таким чином, щоб сформувати найкращу за даних умов відповідь, що багато в чому, залежить від формулювання й отримання питання.

Таким чином, головним у великій запам'ятовуючій системі, якою $є$ довгострокова пам'ять (не їі фізична ємність), яка дозволяє берегти величезну кількість інформації, а ii спроможність у відповідь на поставлене завдання відшукати визначені відомості, вилучити 3 неї інформацію та оперувати у подальшій військовій службі. При цьому треба враховувати факти, які згадуються, що вони зв'язують ті або інші поняття, образи, події, явища i процеси 3 тими поняттями і внутрішніми моделями подій, які вироблені і зафіксовані в пам'яті на основі попереднього досвіду, навчання і здобутих знань. Звідси випливає висновок, що пам'ять $є$ необхідною, але не достатньою умовою набуття наукових і практичних знань для офіцерів. Для знань, крім того, необхідним $\epsilon$ визначений структурний, логічний, понятійний зв'язок інформації, який зберігається в пам'яті офіцера, що досягається засобами педагогічних технологій. Так, пам'ять запам'ятовує велике число образів 3 навколишнього світу і їх поведінку; потім послідовність подій і явищ за участю образів; далі розпізнавання/порівняння образів подій, явищ і процесів на основі судження про їхню подібність i розходження, яке відбувається на різноманітних рівнях, які надходить із відчуттями і існують в пам'яті. От чому образність (наочність, предметність) є основою пам'яті і знань [20].

Офіцер може довільно викликати i розглядати знайомі образи, порівнювати їх один 3 одним i 3 будь-якими іншими моделями, що запропоновані незнайомими образами. Зберігання такого роду копій первинної інформації в пам'яті забезпечує, згодом, велику гнучкість пошукових операцій при з'ясуванні відповідей на питання, що стосуються нашого досвіду. Але, поряд із цим, наявність у пам'яті початкового (вихідного) образу є необхідною 
умовою швидкого запам’ятовування нових, загалом подібних образів на основі аналізу подібності i розходжень істотних, а потім i другорядних ознак, формуючи, таким чином, шлях переходу від часткового до загального. Звідси випливає, по-перше, що все нове повинно базуватися на досвіді старого, i, подруге, якщо подія, об’єкт, явище або процес невідомі і не можуть бути наочно представлені, то необхідно уявити його образ, модель, схему, креслення або картину. Найчастіше пам'ять виступає як складна рекурсивна діяльність головного мозку, яка пов'язана з постановкою питання самому собі. Якщо немає можливості в пошуку відповідей активному і творчому йти точно до цілі, пам'ять розбиває задачу на ряд вторинних проміжних задач і перед кожним таким завданням офіцер ставить питання: «Чи можна таким чином вирішити бойову задачу, чи просуне іï рішення до поставленої мети?». Як тільки вирішена одна задача, яка наближена до мети, формуючий пошук продовжується. У випадку успіху система пам'яті дає відповідь, проте цю відповідь навряд чи можна вважати просто спогадом. Поряд із тим, що було випробувано насправді, існує логічна реконструкція того, що повинно бути випробуване (подібне характерно для ситуацій, які виникають на іспитах) [26, 32].

Можна припустити, що, як у процесі запам'ятовування, так і відповіді на запитання, пам’ять спроможна утримувати в полі зору весь об'єкт i запам’ятовувати або відтворювати подробиці частин і елементів. Цей висновок важливий для педагогіки, оскільки знання про досліджуваний об'єкт потребують початкового докладного розгляду його структури і зв'язків між елементами, після чого заповнюється подробицями кожний елемент i встановлювати його внутрішні зв'язки між ланками, поняттями. 3 усіх наведених міркувань випливає, що в запам'ятовувальній системі фіксується не матеріал і об'єкти нашого досвіду, а зміст цього матеріалу, тобто пам'ять фіксує і зберігає зміст. Отже, офіцер повинен довідуватися, запам'ятовувати, вивчати матеріал тим охочіше, чим повніше він збігається зі змістом, що зберігається в його пам'яті. Пошук інформації закінчується процесом витягу іï 3 пам'яті [29, 37].

Розглянемо цей процес із позицій імітаційного моделювання. Ці системи сприйняття формують у процесі пізнання чуттєві образи досліджуваних об'єктів, тобто уявлення або, іншими словами, створюють суб'єктивні емоційні образи об'єктивної реальності. При цьому реальний об'єкт виступає в якості прообразу, властивості котрого (доступні для людських почуттів) аналізуються системами сприйняття, i, тим самим, почуттєвий образ якби розчленовується на три складові: зоровий образ, слуховий (звуковий) і кінестичний. Ці три образи знаходяться в пам'яті, але не як ізольовані, а як пов'язані між собою. Далі офіцери дізнаються, розпізнають, порівнюють явища, об'єкти, предмети, які властиві їм, процеси руху і взаємодії [36]. Але не все існуюче, навіть у самих простих об'єктах природи, доступне для чуттєвого сприйняття. Багато чого офіцеру доводиться осягати умоглядно на основі уявних представлень, уяви i творчого мислення, що потребує наявності в пам'яті конкретних образів, понять, представлень, тобто визначеного запасу знань. Однак, найчастіше 
знання людини уривчасті, а значить, i пам'ять «береже» велику кількість незрозумілих, погано осмислених, несистематизованих зведень про об'єкти, явища і процеси [22]. Саме тому головним завданням викладача у освітній діяльності $€$ потреба в тому, щоб у пам'яті офіцера складалися i запам'ятовувалися образи предмета пізнання в системно-логічному зв'язку, тобто логіка процесу пізнання повинна враховувати як особливості функціонування систем чуттєвого сприйняття, так i психологічні закономірності функціонування процесів пам’яті мислення [31].

Таким чином, ми прийшли до висновку про необхідність врахування триетапності процесу осмислення інформації: першим етапом стає витяг у офіцера потрібної (базової) інформації 3 пам’яті за допомогою «ключа» (зорового образу, звука або тілесного відчуття тощо), при цьому систему уявлень (візуальна, аудіальна i кінестична), яка використовується для «відкривання пам’яті», називають ведучою. На другому етапі інформацію, витягнуту з пам'яті, потрібно довести до свідомості, тобто за допомогою системи уявлень: зорових, звукових або кінестичних образів. Систему уявлень, яка використовується офіцером для упізнання витягнутої з пам'яті інформації, тобто уявлення іiі у виді образів, називаються репрезентативною. Заключний, третій етап складається з перевірки істинності, повноти інформації, укладеної в образах і уявленнях. У здійсненні цього етапу використовується три системи уявлення, внутрішні відчуття яких на даному етапі працюють як система зворотного зв'язку, що контролює слушність формування уявлень у вигляді узагальнених образів. Систему, що оцінює істинність інформації, поданої свідомості з пам'яті у вигляді образів, називають референтною, при цьому, сигнал оцінки істинності інформації у вигляді образів визначеного типу.

Необхідно зазначити, що кожний етап процесу мислення від початку, коли «витягується» 3 пам'яті потрібна інформація, у проміжку, коли в уяві створюються ті чи інші образи, i, наприкінці, коли оцінюється істинність i повнота інформації, завжди сполучений із визначеними фізіологічними актами, зовнішній прояв яких полягає в жестикуляції, тембрі і стилі мови, зміні пози, потемнінню радужної оболонки очей, русі очей, мікро- рухах рук і пальців, тобто супроводжується мімікою й емоціями, що добре спостерігається [7, 39].

Таким чином, у процесі розумової роботи офіцер якби, блокуючи внутрішній світ і зосереджуючись на зовнішньому, в процесі мислення, пошуків відповіді на питання, рішення задач, насправді, «придивляється в цілком реальному, хоча і дуже незвичайно улаштованому мозковому просторі». 3 одного боку, цей простір має свою макроструктуру, з іншого - в обмеженому мозковому просторі укладена змістова мікроструктура, що фіксує інформацію, одержувану від органів почуттів. В той же час, ця специфічна структура зв'язків між елементами й галузями мозку є основою, завдяки якому офіцер усвідомлює інформацію і формує суб'єктивні образи об’єктивного світу [14, 19, 45].

Проведене нами дослідження дозволяє зробити висновок, що процес адаптації офіцера до умов освітньо-інформаційного середовища можна представити наступною структурною схемою (Рис. 1). 


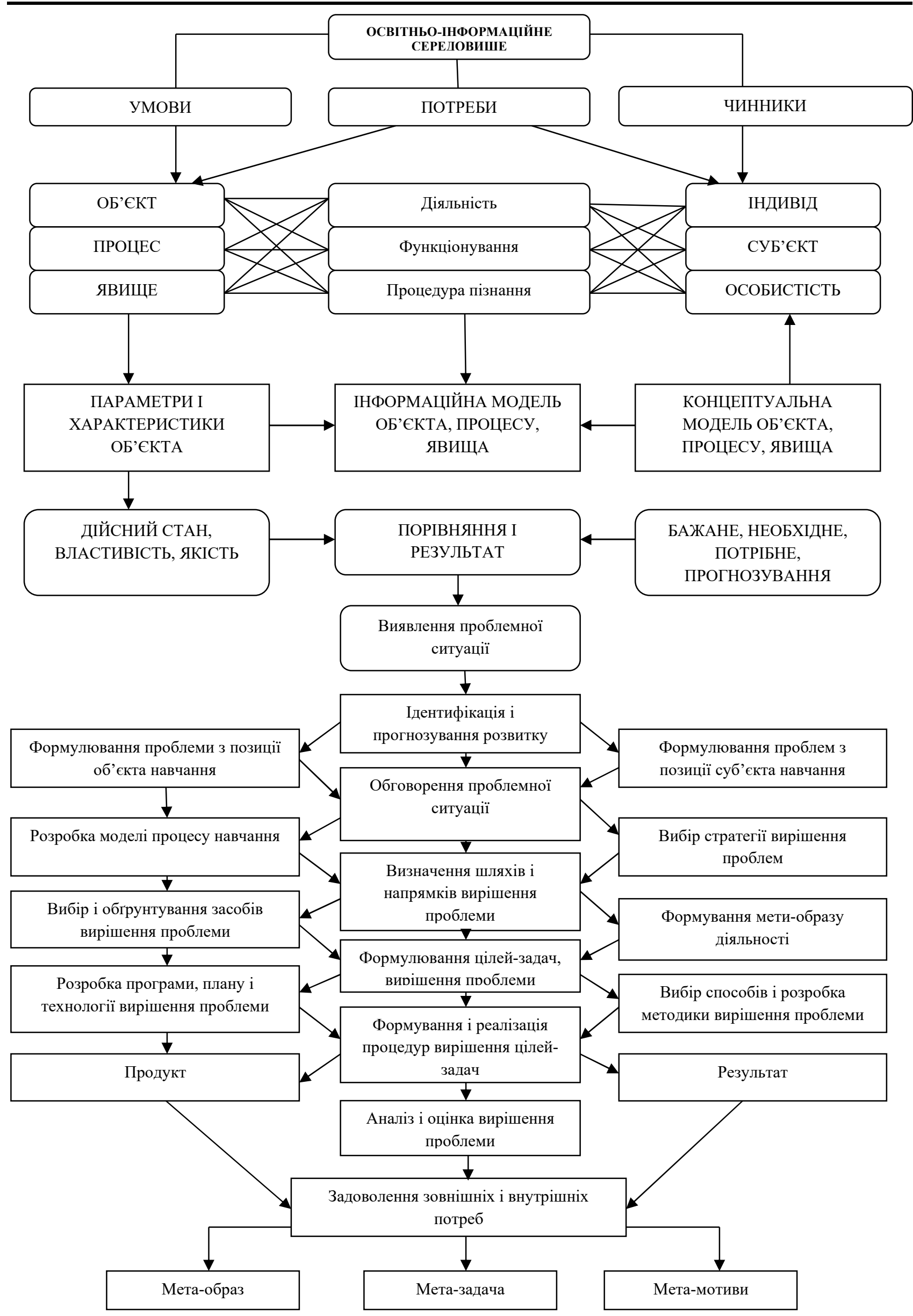

Рис. 1. Структурна схема процесу аналізу інформації офіцерами в умовах в умовах ОІС 
Виходячи 3 того, що освітньо-інформаційне середовище, яке будучі побудованим за ієрархічним принципом, на кожному рівні вирішує задачі навчання, які знаходяться в сфері компетентностей даного рівня підготовки та має включати в себе наступні елементи:

- $\quad$ процес, повний стан якого описується N-мірним простором подій;

- комплекс систем вимірювання стану досліджуваної системи 3 кількістю цих компонентів $-\mathrm{n}(\mathrm{n}<\mathrm{N})$;

- $\quad$ дані події переводяться в n - мірну модель об'єкту і відтворюються на засобах відображення інформації;

- структура навчально-наукової лабораторії та викладачі, які задіяні в організації освітньо-інформаційного середовища;

- організація освітнього процесу відбувається на основі порівняння моделі діяльності офіцера та моделі реального стану цього ж суб'єкту, яке реалізується або у вигляді впливів на освітній процес, або у вигляді наказів, які віддаються офіцеру.

Таким чином, офіцер стає ланкою освітньо-інформаційного середовища, що $є$ інструментальним засобом реалізації його освітньої діяльності. Хоча раціональна організація освітнього процесу $\epsilon$ одним із основних i найважливіших факторів, які визначають ефективне функціонування освітньої системи, однак, в більшості випадків, навчання відбувається не за прямим управлінням суб'єктом навчання, оскільки в умовах освітньо-інформаційного середовища викладач не задіяний у прямій взаємодії з офіцером тому, що між суб'єктом навчання і викладачем знаходиться інформаційна модель даного об'єкту (засоби відображення інформації).

Тому, на часі, постає проблема проектування не тільки засобів відображення інформації, але й засобів взаємодії викладача 3 освітньоінформаційним середовищем, тобто проблема проектування системи інтерфейса (зв'язку) взаємодії. Задача полягає в тому, щоб створити такий інтерфейс (зв'язок) взаємодії, який відповідав би можливостям офіцера по прийому та переробці всього потоку інформації, тобто, щоб інтерфейс взаємодії містив лише ті властивості та зв'язки, які суттєві для організації освітнього процесу, а саме: мова йде про характер, об'єм та вид інформації; урахування дидактичних закономірностей навчальної системи, швидкості оброблення інформації та інтенсивності засвоєння знань; співмірності з можливостями офіцера при опрацюванні навчального матеріалу; типи інформаційних пристроїв; види, форми, колір та їх взаємне розташування; формулювання мети тощо (Рис. 2). Таким чином, ми довели, що точність, швидкість та ефективність складових організації освітнього процесу залежить від інформаційного забезпечення.

Крім того, однією 3 характерних особливостей ергатичних (людиномашинних) систем $\epsilon$ наявність інформаційних потоків в тих контурах регулювання, які замикаються через офіцера, пропускна здатність якого (швидкість сприймання, усвідомлення і переробки інформації) $\epsilon$, нажаль, обмеженою і до того ж змінною величиною [33]. Крім того, якщо враховувати, що офіцеру надається інформація від оточуючого середовища, то існує 
необхідність оптимізації представленої інформації як по часу, так і по об'єму, що ставить особливі вимоги до інформатизації освітнього процесу, а саме: потрібно вирішити, який параметр необхідно перетворити у сигнал, що $\epsilon$ подразником того чи іншого органу відчуття офіцера i був для нього зрозумілим [17].

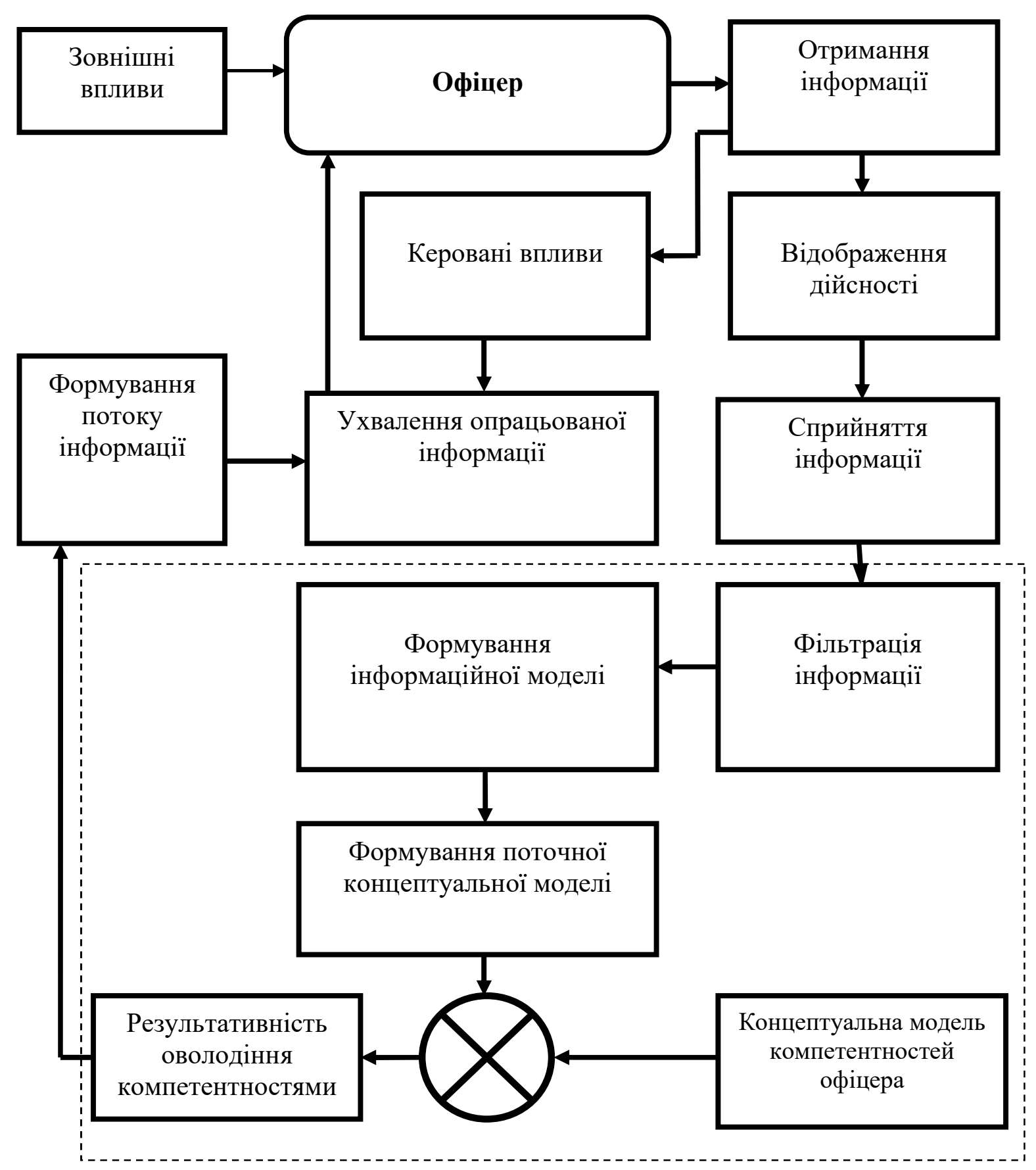

Рис. 2. Інформаційне забезпечення освітнього процесу в умовах освітньо-інформаційного середовища ВВНЗ

Відомо в процесі сприймання інформації офіцером освітній матеріал надається за допомогою інформаційних систем. В більшості випадків ці інформаційні системи (формулювання, трансляція, переробка інформації тощо) 
мають багатоступінчате перетворення 3 використанням методів і пристроїв обробки інформації на проміжних фазах (ступенях) передачі інформації (наприклад, перетворення за типом: механічне переміщення - електричний сигнал - обробка (фільтрація) - механічне переміщення - візуальний сигнал). Таким чином інформаційні системи фактично формують потокові ланцюги, канали передачі інформації, починаючи з вимірювальних програмних продуктів i закінчуючи засобами відображення інформації [24]. Однак, сприйняття i переробка інформації офіцером обмежується, як відомо, психофізіологічними можливостями, які суттєво відрізняються у різних індивідуумів і залежать від зовнішніх умов і психофізиологічного стану самого офіцера [44]. Таким чином, кількість сприйнятої офіцером інформації повинна бути достатньою, але не надлишковою для формування знань на основі інформаційної моделі [18]. Саме тому, при створенні освітньо-інформаційного середовища, в першу чергу, вирішуються параметри роботи ергатичної системи, які будуть представлені офіцеру у відповідному вигляді, враховуючи іiі особливості - вона повинна повністю описувати поведінку і стан об'єкту навчання. Встановлюються модальність сигналів (до якого офіцера їх адресувати), ступінь обробки інформації, вид і характер іï представлення і розміщення елементів системи відображення інформації (CBI).

При цьому спосіб представлення інформації (зорової, слухової, кінестичної) забезпечується швидким стимулюванням різних аналізаторів офіцера, які сприймаються та переробляються, тобто мають найбільш ефективний код та дозволяють безпомилково декодувати сприйняте повідомлення, яке несе інформаційна модель, що надає можливість (коли це необхідно) успішно реалізувати отриманні знання. Сприймаючи інформацію органами відчуття, офіцер переробляє іiі на свідомому або напівсвідомому рівні, відповідним чином декодує iі, ототожнюе i зіставляє iз сформованою концептуальною моделлю (KM), що відповідає уявленням викладача про необхідний стан і поведінку суб'єкта навчання, яка формується у свідомості офіцера в процесі учіння i професіональної підготовки до даного роду діяльності. Якість і повнота КМ суттєвим чином залежать від мотивації офіцера, досвіду і компетентностей набутих при навчанні. КМ - основа для прогнозування розвитку подій і поведінки ергатичної системи, для освітнього процесу, яке формується на основі рівня знань офіцерів.

Висновки та перспективи подальших досліджень. Таким чином, концептуальна модель освітнього процесу відіграє вирішальну роль у процесі використання педагогічних технологій в освітньо-інформаційному середовищ. Освітньо-інформаційне середовище спрямоване на позитивні зміни у підготовці офіцерів ВВН3, що дає можливість використовувати у освітньому процесі інтегральний підхід, сутність якого полягає у тому, що за допомогою інформаційних систем, а саме, постійного супроводу та створення власної освітньої траєкторії навчання у офіцера, формуються компетентності.

У роботі досліджено особливості інтегрування офіцера в освітньоінформаційне середовище, що визначається представлення елементів ОІС, як таких, що опрацьовують (специфічним чином) інформацію та описують 
процеси в ньому. Також було встановлено, що доцільно розглядати освітньоінформаційне середовище не як механічну систему, у яку інтегрується офіцер, а як інформаційну систему 3 функціональним інтегруванням «офіцер - OІС». Крім того, розглянуто технологію навчання, що полягає у сукупності методів та засобів для реалізації відповідного змісту підготовки в умовах освітньоінформаційного середовища.

Перспективи подальших досліджень полягають у синтезі досягнень педагогічної теорії та практики, сполучення традиційних елементів минулого досвіду i того, що $є$ породженням суспільного прогресу, гуманізації та демократизації суспільства.

\section{ЛІТЕРАТУРА}

1. Арістова, Н. О. (2015).Переваги і перспективи впровадження відкритих освітніх електронних ресурсів у процес професійної підготовки майбутніх філологів.К. : Гнозис, Гуманітарний вісник ДВНЗ «Переяслав-Хмельницький державний педагогічний університет імені Григорія Сковороди», додаток 1 до вип. 36, Том IV (64) : тематич. вип. «Вища освіта України у контексті інтеграції до європейського освітнього простору», 24-31.

2. Артюшина, М.В., Котикова,О. М., Романова, Г. М та ін. (2007). Психологопедагогічні аспекти реалізації сучасних методів навчання у вищій школі: Навч. посіб. К. : КНЕУ, с. 528.

3. Барановська, Л. В.(2013). Педагогіка та психологія вищої школи : навч. посібн. К. : HAУ, c. 254.

4. Берулава, Г. А. (2009). Методологические ориентиры современной психологии. Монография. М. : Изд-во Университета Российской академии образования, с. 176.

5. Буль, Е. Е. (2003). Обзор моделей студента для компьютерных систем обучения. Educational Technology and Society. V. 6., № 4, 245-250.

6. Власенко, Г. М., Куровська, Т. Ю. (2011). Аналіз можливих методів прийняття рішень людиною. Труди університету : зб. наук. Праць. Національний університет оборони України імені Івана Черняховського. К., № 3 (119), 176-181.

7. Гончаренко, С. У. (1997). Український педагогічний словник. К. : Либідь, с. 375.

8. Жук, Ю.О. (2007). Теоретико-методологічні проблеми формування інформаційного освітнього простору України. Інформаційні технології і засоби навчання. Т. 3, № 2. Взято 3http://journal.iitta.gov.ua/index. php/itlt/issue/view/23.

9. Захарова, И. Г. (2003). Информационные технологии в образовании : Учеб. пособие для студ. высш. пед. учеб. заведений. М. : Издательский центр «Акалемия»,с. 192.

10. Корсак, К. В., Корсак, Ю. К., Тарутіна, 3. Є., Похресник, А. К., Козлакова, Г. О. (2012). Теоретичні засади моніторингу якості вищої природничої та інженерної освіти. Монографія. НАПН України, Ін-т вищ. освіти. К. : Пед. думка, с. 207.

11. Кучерявий, А. О. (2012). Функціональні характеристики самостійної роботи майбутніх юристів у контексті управління самостійною навчальною діяльністю офіцерів. Наукові праці Донецького національного ВВНЗ. Серія "Педагогіка, психологія і соціологія": збірник наукових праць. Донецьк, випуск 11 (202), 95-98.

12. Литвиненко, Г. М. (2013). Формування науково-методичного середовища : обгрунтування засад та визначення критеріїв ефективності функціонування. К. : Рідна школа, № 6, 57-63.

13. Мадзігон, В. М. (2010). Дидактичні вимоги до електронних підручників. Проблеми сучасного підручника: зб. наук. праць, вип. 10. К. : Ін-т педагогіки НАПН України, 4-7.

14. Машбиць, Ю. І. (2009). Навчальна технологія (психологічний аналіз). Актуальні проблеми психології : Психологічна теорія і технологія навчання. К. : Вид-во НПУ імені М. П. Драгоманова,. Т. 8, № 6. 166-177. 
15. Морзе, Н. В. (2003). Система методичної підготовки майбутніх вчителів інформатики в педагогічних університетах. Автореф. дис. д-ра пед. наук: 13.00.02 / Нац. педагогічний ун-т ім. М. П. Драгоманова. К., с. 39.

16. Мусенова, Э. А., Ахметов,М. А. (2007). Развитие представлений о строении вещества при изучении химии в старшей школе. Ульяновск: УИПКПРО, с. 63.

17. Подиновский, В. В., Ногин,В. Д. (1982). Парето-оптимальные решения многокритериальных задач. М. : Наука, с. 142.

18. Рахманов, В. О. (2013). Аналіз методики сприймання інформації студентами у вищому технічному навчальному закладі. Вісник Національного авіаційного університету. Серія : Педагогіка. Психологія : зб. наук. праць. К : НАУ, вип. 1(4), 110-112.

19. Рахманов, В. О. (2017). Інтеграція офіцера в освітньо-інформаційне середовище BBH3. Scientific letters of Academic Society of Michal Baludansky. Kosice, Slovakia, 5(2), 96-99.

20. Рахманов, В. О. (2016). Інтеграція офіцера в освітньо-інформаційне середовище, як один із ефективних способів підвищення рівня підготовки офіцерів у вищих технічних навчальних закладах. Класичний університет у контексті викликів епохи: матеріали українсько-польської міжнар. наукової конф., 22-23 вересня 2016 р.: тези доп. К.: Київський нац. університет ім. Т. Шевченка, 76-78.

21. Рахманов, В. О. (2016). Методичні засади підготовки офіцерів в умовах освітньоінформаційного середовища ВВНЗ. Science and Education a New Dimension. Pedagogy and Psychology, IV (41), Issue: 86, 37-41.

22. Рахманов, В.О. (2018). Розвиток свідомості офіцера в умовах освітньоінформаційного середовища ВВНЗ. Психологія свідомості: теорія і практика наукових досліджень. Міжнар. наук.-практ. конф., 21 березня 2018 р.: тези доп. ПереяславХмельницький, 184-188.

23. Рахманов, В. О. (2015). Формування освітньо-інформаційного середовища вищого навчального закладу. Актуальні проблеми вищої професійної освіти України : Міжнар. наук.практ. конф., 19 березня 2015 р. : тези доп. К., 76-77.

24. Рахманов, В. О. (2018). Формування знань, умінь та навичок у майбутніх інженерах в умовах освітньо-інформаційного середовища ВВНЗ. Вісник Національного авіаційного університету. Серія : Педагогіка. Психологія : зб. наук. праць. К : НАУ, вип. 1(12), 93-97.

25. Семиченко, В. А., Заслуженюк, В. С. (2000). Психологічна структура педагогічної діяльності : навч. посібник. К. : Київський національний ун-т ім. Тараса Шевченка, Ч. 1, с 217.

26. Семиченко, В. А. (2004). Психологія педагогічної діяльності : навч. посібник для студ. вищих пед. навч. закл. К. : Вища школа, с. 336.

27. Сисоєва, С. О. (2006). Створення і впровадження електронних навчальних засобів: теоретичний аналіз проблеми. Неперервна професійна освіта. К., Ч. І., вип. 1/2, 124-131.

28. Совгіра, С. В. (2013). Роль діяльності і активності людини в процесі пізнання навколишнього світу. Природничі науки в системі освіти: матер. Міжнар. наук.-практ. інтернет-конф. Умань : ПП Жовтий О. О., 163-168.

29. Урбанович, А. А. (2001). Психология управления : учеб.пособ. Минск : Харвест, с. 640.

30. Федорова, I. І., Трофименко, Я. В. (2012). Академічна мобільність українських офіцерів сучасного освітнього простору. Вісник Національного ВВНЗ України «Київський політехнічний інститут». Філософія. Психологія. Педагогіка : Зб. наук. праць. К.: ВПК Політехніка, № 2 (35). 139-144.

31. Baddeley, A., Andrade, J. (2000). Working memory and the vividness of imagery. Journal of Experimental Psychology : General, V. 129, 126-145.

32. Baddeley, A. (2001). Is working memory still working? American Psychologist, V. 56, $851-864$.

33. Baldiris, S., Fabregat, R., Mejía, C., Gómez, S. (2009).Adaptation decisions and profiles exchange among open learning management systems based on agent negotiations and machine 
learning techniques. Human-computer interaction. interacting in various application domains. lecture notes in computer science. V. 5613, 12-20.

34. Cruz-Neira, C., Sandin, D. J., DeFanti,T. A., Kenyon, R. V., Hart J. C. (1992). The CAVE: Audio Visual Experience Automatic Virtual Environment. Communications of the ACM, V. 35, No 6, 64-72.

35. Dinçol, S., Temel, S., Oskay, Ö. Ö., Erdogan, Ü. I., Yilmaz, A. (2011). The effect of matching learning styles with teaching styles on success. Procedia Social and Behavioral Sciences, V. $15,854-858$.

36. Drobot, O. V. (2014). Phenomenology and conditions of formation of managerial conscience as a systemic formation of psyche. Fundamental and applied researches in practice of leading scientific schools. Issue: 1 / Ed. by R. Iserman, V. Lunov / Publishing office: Accent Graphics Communications. Hamilton, ON - Canada, 53 - 68.

37. Engelkamp, J., Seiler, K. H. (2003). Gains and losses in action memory.The Quarterly Journal of Experimental Psychology, V. A56, 829-848.

38. Franzoni, A. L., Assar, S. (2009). Student learning styles adaptation method based on teaching strategies and electronic media. Journal of International Forum of Educational Technology and Society, V. 12, 407, № 4, 15-29.

39. Husch, D. S. (2001). An investigation of the relationships between learning styles, personality temperaments, mathematical self-efficacy, and post-secondary calculus achievement. A Dissertation Presented for the Doctor of Philosophy Degree. The University of Tennessee, USA, p.197.

40. Leinhardt, G. Zaslavsky, O., Stein M. (1990). K. Function, graphs, and graphing: tasks, learning and teaching. Review of Educational Research, V. 60, 1-64.

41. Leopold, C., Leutner, D. (2012). Science text comprehension: Drawing, main idea selection, and summarizing as learning strategies. Learning and Instruction, V. 22, 16-26.

42. Liu, H., Andre,T., Greenbowe, T. (2008). The impact of learner's prior knowledge on their use of 412 chemistry computer simulations: a case study. Journal of Science Education and Technology, V. 17, 466-482.

43. Nachmias, R., Tuvi, I. (2001). Taxonomy of scientifically oriented educational websites. Journal of Science Education and Technology, V. 10, 93-104.

44. Schüler, A., Scheiter, K., Rummer, R., Gerjets, P. (2012). Explaining the modality effect in multimedia learning: Is it due to a lack of temporal contiguity with written text and pictures? Learning and Instruction, V. 22, 92-102.

45. Snir, J., Smith,C. L., Raz, G. (2003). Linking phenomena with competing underlying models: a software tool for introducing students to the particulate model. Science Education, V. 87, 794-830.

46. Standards for Technology literacy: Content for the study of technology education, association and its technology for all American Project, Reston (2000). Virginia, p. 248.

47. Sung, E., Mayer,R. E. (2012). Students' beliefs about mobile devices Vs. desktop computers in South Korea and the United States. Computers \& Education, V. 59, 1328-1338.

\section{REFERENCES}

1. Aristova, N. O. (2015).Perevahy i perspektyvy vprovadzhennia vidkrytykh osvitnikh elektronnykh resursiv u protses profesiinoi pidhotovky maibutnikh filolohiv.K. : Hnozys, Humanitarnyi visnyk DVNZ «Pereiaslav-Khmelnytskyi derzhavnyi pedahohichnyi universytet imeni Hryhoriia Skovorody», dodatok 1 do vyp. 36, Tom IV (64) : tematych. vyp. «Vyshcha osvita Ukrainy u konteksti intehratsii do yevropeiskoho osvitnoho prostoru», 24-31.

2. Artiushyna, M. V., Kotykova,O. M., Romanova, H. M ta in. (2007). Psykholohopedahohichni aspekty realizatsii suchasnykh metodiv navchannia u vyshchii shkoli: Navch. posib. K. : KNEU, s. 528.

3. Baranovska, L. V.(2013). Pedahohika ta psykholohiia vyshchoi shkoly : navch. posibn. K. : NAU, s. 254. 
4. Berulava, H. A. (2009). Metodolohycheskye oryentyry sovremennoi psykholohyy. Monohrafyia. M. : Yzd-vo Unyversyteta Rossyiskoi akademyy obrazovanyia, s. 176.

5. Bul, E. E. (2003). Obzor modelei studenta dlia kompiuternykh system obuchenyia. Educational Technology and Society. V. 6., № 4, 245-250.

6. Vlasenko, H. M., Kurovska, T. Yu. (2011). Analiz mozhlyvykh metodiv pryiniattia rishen liudynoiu. Trudy universytetu : zb. nauk. Prats. Natsionalnyi universytet oborony Ukrainy imeni Ivana Cherniakhovskoho. K., № 3 (119), 176-181.

7. Honcharenko, S. U. (1997). Ukrainskyi pedahohichnyi slovnyk. K. : Lybid, s. 375.

8. Zhuk, Yu. O. (2007). Teoretyko-metodolohichni problemy formuvannia informatsiinoho osvitnoho prostoru Ukrainy. Informatsiini tekhnolohii i zasoby navchannia. T. 3, № 2. Vziato zhttp://journal.iitta.gov.ua/index. php/itlt/issue/view/23.

9. Zakharova, Y. H. (2003). Ynformatsyonnye tekhnolohyy v obrazovanyy : Ucheb. posobye dlia stud. vyssh. ped. ucheb. zavedenyi. M. : Yzdatelskyi tsentr «Akalemyia»,s. 192.

10. Korsak, K. V., Korsak, Yu. K., Tarutina, Z. Ye., Pokhresnyk, A. K., Kozlakova, H. O. (2012). Teoretychni zasady monitorynhu yakosti vyshchoi pryrodnychoi ta inzhenernoi osvity. Monohrafiia. NAPN Ukrainy, In-t vyshch. osvity. K. : Ped. dumka, s. 207.

11. Kucheriavyi, A. O. (2012). Funktsionalni kharakterystyky samostiinoi roboty maibutnikh yurystiv u konteksti upravlinnia samostiinoiu navchalnoiu diialnistiu ofitseriv. Naukovi pratsi Donetskoho natsionalnoho VVNZ. Seriia "Pedahohika, psykholohiia i sotsiolohiia": zbirnyk naukovykh prats. Donetsk, vypusk 11 (202), 95-98.

12. Lytvynenko, H. M. (2013). Formuvannia naukovo-metodychnoho seredovyshcha : obgruntuvannia zasad ta vyznachennia kryteriiv efektyvnosti funktsionuvannia. K. : Ridna shkola, № 6, 57-63.

13. Madzihon, V. M. (2010). Dydaktychni vymohy do elektronnykh pidruchnykiv. Problemy suchasnoho pidruchnyka: zb. nauk. prats, vyp. 10. K. : In-t pedahohiky NAPN Ukrainy, 4-7.

14. Mashbyts, Yu. I. (2009). Navchalna tekhnolohiia (psykholohichnyi analiz). Aktualni problemy psykholohii : Psykholohichna teoriia i tekhnolohiia navchannia. K. : Vyd-vo NPU imeni M. P. Drahomanova,. T. 8, № 6. 166-177.

15. Morze, N. V. (2003). Systema metodychnoi pidhotovky maibutnikh vchyteliv informatyky v pedahohichnykh universytetakh. Avtoref. dys. d-ra ped. nauk: 13.00.02 / Nats. pedahohichnyi un-t im. M. P. Drahomanova. K., s. 39.

16. Musenova, Э. A., Akhmetov,M. A. (2007). Razvytye predstavlenyi o stroenyy veshchestva pry yzuchenyy khymyy v starshei shkole. Ulianovsk: UYPKPRO, s. 63.

17. Podynovskyi, V. V., Nohyn,V. D. (1982). Pareto-optymalnыe reshenyia mnohokryteryalnыkh zadach. M. : Nauka, s. 142.

18. Rakhmanov, V. O. (2013). Analiz metodyky spryimannia informatsii studentamy u vyshchomu tekhnichnomu navchalnomu zakladi. Visnyk Natsionalnoho aviatsiinoho universytetu. Seriia : Pedahohika. Psykholohiia : zb. nauk. prats. K : NAU, vyp. 1(4), 110-112.

19. Rakhmanov, V. O. (2017). Intehratsiia ofitsera v osvitno-informatsiine seredovyshche VVNZ. Scientific letters of Academic Society of Michal Baludansky. Kosice, Slovakia, 5(2), 96-99.

20. Rakhmanov, V. O. (2016). Intehratsiia ofitsera v osvitno-informatsiine seredovyshche, yak odyn iz efektyvnykh sposobiv pidvyshchennia rivnia pidhotovky ofitseriv u vyshchykh tekhnichnykh navchalnykh zakladakh. Klasychnyi universytet u konteksti vyklykiv epokhy: materialy ukrainsko-polskoi mizhnar. naukovoi konf., 22-23 veresnia 2016 r.: tezy dop. K.: Kyivskyi nats. universytet im. T. Shevchenka, 76-78.

21. Rakhmanov, V. O. (2016). Metodychni zasady pidhotovky ofitseriv v umovakh osvitnoinformatsiinoho seredovyshcha VVNZ. Science and Education a New Dimension. Pedagogy and Psychology, IV (41), Issue: 86, 37-41.

22. Rakhmanov, V. O. (2018). Rozvytok svidomosti ofitsera v umovakh osvitnoinformatsiinoho seredovyshcha VVNZ. Psykholohiia svidomosti: teoriia i praktyka naukovykh doslidzhen. Mizhnar. nauk.-prakt. konf., 21 bereznia 2018 r.: tezy dop. Pereiaslav-Khmelnytskyi, 184-188. 
23. Rakhmanov, V. O. (2015). Formuvannia osvitno-informatsiinoho seredovyshcha vyshchoho navchalnoho zakladu. Aktualni problemy vyshchoi profesiinoi osvity Ukrainy : Mizhnar. nauk.-prakt. konf., 19 bereznia 2015 r. : tezy dop. K., 76-77.

24. Rakhmanov, V. O. (2018). Formuvannia znan, umin ta navychok u maibutnikh inzhenerakh $\mathrm{v}$ umovakh osvitno-informatsiinoho seredovyshcha VVNZ. Visnyk Natsionalnoho aviatsiinoho universytetu. Seriia : Pedahohika. Psykholohiia : zb. nauk. prats. K : NAU, vyp. 1(12), 93-97.

25. Semychenko, V. A., Zasluzheniuk, V. S. (2000). Psykholohichna struktura pedahohichnoi diialnosti : navch. posibnyk. K. : Kyivskyi natsionalnyi un-t im. Tarasa Shevchenka, Ch. 1, s 217.

26. Semychenko, V. A. (2004). Psykholohiia pedahohichnoi diialnosti : navch. posibnyk dlia stud. vyshchykh ped. navch. zakl. K. : Vyshcha shkola, s. 336.

27. Sysoieva, S. O. (2006). Stvorennia i vprovadzhennia elektronnykh navchalnykh zasobiv: teoretychnyi analiz problemy. Neperervna profesiina osvita. K., Ch. I., vyp. 1/2, 124-131.

28. Sovhira, S. V. (2013). Rol diialnosti i aktyvnosti liudyny v protsesi piznannia navkolyshnoho svitu. Pryrodnychi nauky v systemi osvity: mater. Mizhnar. nauk.-prakt. internetkonf. Uman : PP Zhovtyi O. O., 163-168.

29. Urbanovych, A. A. (2001). Psykholohyia upravlenyia : ucheb.posob. Mynsk : Kharvest, s. 640 .

30. Fedorova, I. I., Trofymenko, Ya. V. (2012). Akademichna mobilnist ukrainskykh ofitseriv suchasnoho osvitnoho prostoru. Visnyk Natsionalnoho VVNZ Ukrainy «Kyivskyi politekhnichnyi instytut». Filosofiia. Psykholohiia. Pedahohika : Zb. nauk. prats. K.: VPK Politekhnika, № 2 (35). 139-144.

31. Baddeley, A., Andrade, J. (2000). Working memory and the vividness of imagery. Journal of Experimental Psychology : General, V. 129, 126-145.

32. Baddeley, A. (2001). Is working memory still working? American Psychologist, V. 56, $851-864$.

33. Baldiris, S., Fabregat, R., Mejía, C., Gómez, S. (2009).Adaptation decisions and profiles exchange among open learning management systems based on agent negotiations and machine learning techniques. Human-computer interaction. interacting in various application domains. lecture notes in computer science. V. 5613, 12-20.

34. Cruz-Neira, C., Sandin, D. J., DeFanti,T. A., Kenyon, R. V., Hart J. C. (1992). The CAVE: Audio Visual Experience Automatic Virtual Environment. Communications of the ACM, V. 35, No 6, 64-72.

35. Dinçol, S., Temel, S., Oskay, Ö. Ö., Erdogan, Ü. I., Yilmaz, A. (2011). The effect of matching learning styles with teaching styles on success. Procedia Social and Behavioral Sciences, V. $15,854-858$.

36. Drobot, O. V. (2014). Phenomenology and conditions of formation of managerial conscience as a systemic formation of psyche. Fundamental and applied researches in practice of leading scientific schools. Issue: 1 / Ed. by R. Iserman, V. Lunov / Publishing office: Accent Graphics Communications. Hamilton, ON - Canada, 53 - 68.

37. Engelkamp, J., Seiler, K. H. (2003). Gains and losses in action memory.The Quarterly Journal of Experimental Psychology, V. A56, 829-848.

38. Franzoni, A. L., Assar, S. (2009). Student learning styles adaptation method based on teaching strategies and electronic media. Journal of International Forum of Educational Technology and Society, V. 12, 407, № 4, 15-29.

39. Husch, D. S. (2001). An investigation of the relationships between learning styles, personality temperaments, mathematical self-efficacy, and post-secondary calculus achievement. A Dissertation Presented for the Doctor of Philosophy Degree. The University of Tennessee, USA, r.197.

40. Leinhardt, G. Zaslavsky, O., Stein M. (1990). K. Function, graphs, and graphing: tasks, learning and teaching. Review of Educational Research, V. 60, 1-64. 
41. Leopold, C., Leutner, D. (2012). Science text comprehension: Drawing, main idea selection, and summarizing as learning strategies. Learning and Instruction, V. 22, 16-26.

42. Liu, H., Andre,T., Greenbowe, T. (2008). The impact of learners prior knowledge on their use of 412 chemistry computer simulations: a case study. Journal of Science Education and Technology, V. 17, 466-482.

43. Nachmias, R., Tuvi, I. (2001). Taxonomy of scientifically oriented educational websites. Journal of Science Education and Technology, V. 10, 93-104.

44. Schüler, A., Scheiter, K., Rummer, R., Gerjets, P. (2012). Explaining the modality effect in multimedia learning: Is it due to a lack of temporal contiguity with written text and pictures? Learning and Instruction, V. 22, 92-102.

45. Snir, J., Smith,C. L., Raz, G. (2003). Linking phenomena with competing underlying models: a software tool for introducing students to the particulate model. Science Education, V. 87, 794-830.

46. Standards for Technology literacy: Content for the study of technology education, association and its technology for all American Project, Reston (2000). Virginia, r. 248.

47. Sung, E., Mayer,R. E. (2012). Students beliefs about mobile devices Vs. desktop computers in South Korea and the United States. Computers \& Education, V. 59, 1328-1338.

\section{PЕЗЮМЕ}

Виталий Рахманов,

доктор педагогических наук, доцент

Национальный университет обороны Украины имени Ивана Черняховского

\section{Теоретические основы подготовки офицеров в условиях образовательно- информационной среды высшего военного учебного заведения}

В статье рассматриваются особенности интеграџии офиџера в образовательноинформачионную среду, которая обрабатывает (специильным способом) информачию и описывают прочессы в нем. Так же было определено, что лучше рассматривать образовательно-информационную среду не как механическую систему, в которую интегрируется офицер, а как систему с функциональной интеграцией «офищер - ОИС». Кроме этого, рассмотрено технологию обучения, которая состоит из совокупности методов и средств для реализации соответственного содержания подготовки в условиях образовательно-информационной среды. В роботе проанализировано, что при наличии развитой информаџионной базы новые понятия могут запоминаться, в основном, по аналоги с теми знаниями, которые были известны, и главной проблемой становиться включение нового знания в существующую структуру: как только определено правильное соотношение, тогда весь материал прошлого автоматически привлекаться к изложению и пониманию новых событий, развивается путем взаимодействия внешнего опьта $u$ внутренних механизмов, оперируется информаџия, которая приходит, а также реорганизуется.

Ключевые слова: образовательно-информачионная среда; подготовка офицеров; высшее военное учебное заведение.

\section{SUMMARY}

Vitaliy Rakhmanov,

Dr. (Pedagogical Sciences), associate professor National Defense University of Ukraine named after Ivan Chernyakhovskii 


\section{Theoretical fundamentals of training of officers in the conditions of the educational and information environment of the higher military educational institution}

The article discusses the features of the officer's integration into the educational and information environment, which processes (in a special way) information and describes the processes in it. It was also determined that it is better to consider the educational information environment not as a mechanical system into which an officer is integrated, but as a system with functional integration "officer - EIE". In addition, the technology of training, which consists of a set of methods and means for implementing the relevant content of training in the educational and informational environment, is considered. The machine analyzed that with a developed information base, new concepts can be remembered, mainly by analogs with the knowledge that was known, and the main problem is the inclusion of new knowledge in the existing structure: as soon as the correct correlation is determined, then all the material of the past is automatically involved in the presentation and understanding of new events, develops through the interaction of external experience and internal mechanisms, the information that comes in and is reorganized is operated on.

Key words: educational and informational environment; officer training; higher military educational institution. 